\title{
EL SENTIDO FIGURADO DEL SONNET XVI DE WILLIAM SHAKESPEARE Y SU TRADUCCIÓN AL ESPAÑOL
}

\author{
Jesús Ángel Marín Calvarro \\ Universidad de Extremadura
}

\begin{abstract}
One of the most important features of the language used by W. Shakespeare in his works is, undoubtedly, the great number of puns, ambiguities, innuendoes, and word play in general that this author handles with superb craftsmanship. While the use of word play greatly enriches Shakespearian discourse, at the same time, it defies easy translation. This paper seeks to identify and explain the ambiguities that embellish Sonnet $X V I$, and evaluates some of the most important translations into Spanish
\end{abstract}

\section{SONNET XVI}

But wherefore do not you a mightier way

Make war upon this bloody tyrant time?

And fortify yourself in your decay

With means more blessèd than my barren rhyme?

Now stand you on the top of happy hours,

And many maiden gardens yet unset,

With virtuous wish would bear your living flowers,

Much liker than your painted counterfeit.

So should the lines of life that life repair

Which this time's pencil or my pupil pen

Neither in inward worth nor outward fair

Can make you live yourself in eyes of men.

To give away yourself keeps yourself still,

And you must live, drawn by your own sweet skill'.

\section{INTRODUCCIÓN}

El juego polisémico del "Sonnet XVI", el mayor logro quizá del estilo del poema, se perfila también como uno de los aspectos más refractarios a la traducción?2. El escollo principal radica en una serie coherente de equívocos que, distribuidos calculadamente a lo

\footnotetext{
${ }^{1}$ El texto del soneto pertenece a la edición de S. Booth. Shakespeare's Sonnets, New Haven, Yale University Press, 1977

${ }^{2}$ Las traducciones de los sonetos de W. Shakespere al español que se utilizan en este trabajo de investigación son las de Luis Astrana Marín, Eduardo Dieste, Angelina Damians de Bulart, Mariano de Vedia y Mitre, Manuel Mujica Láinez, José Basileo Acuña, Agustín García Calvo, Fátima Auad y Pablo Mañé Garzón, José Méndez Herrera, Enrique Sordo, Miguel Ángel Montezanti, Carmen Pérez Romero, Carlos Pujol, Gustavo Falaquera, José María Álvarez y Alfredo Gómez Gil.
} 
largo del soneto, generan esa dialéctica tan peculiar del lenguaje literario y de la propia cosmovisión del autor isabelino. De ahí que, para valorar el alcance y la fidelidad de cualquier traducción, haya que sacar a la luz esos sentidos soterrados que, fruto de la ambigüedad, constituyen, si no el significado profundo del soneto, al menos su otra cara, es decir, ese auténtico subtexto que se contrapone a la primera lectura de estos versos y la completa a la vez. El estudio de esta dimensión no agota, por supuesto, su rica complejidad artística, ni basta, por lo tanto, para poder abordar o evaluar la tarea creadora de traducción. Habría que analizar, además, aspectos tan esenciales como, por ejemplo, el modelo prosódico, el esquema rítmico o suprasegmental, y la distribución sintáctica correspondientes en el texto de llegada. No obstante, por afectar de manera directa al significado, el tema que aquí se propone resulta fundamental para la propia inteligibilidad del texto y, en consecuencia, su estudio ha de ser previo a todos los demás. La fórmula que aquí se propone para sacar a la luz ese peculiar componente de los sonetos del autor isabelino es a la vez sencilla y compleja. Resulta simple por cuanto que se trata de localizar y fijar aquellos términos marcados por el juego lingüístico y la polisemia para, a continuación, efectuar una comparación de esos segmentos con las respuestas que proponen los traductores en el texto de llegada. Pero la localización y fijación de esos espacios ambiguos exige una consulta en profundidad de la ingente crítica textual, labor editora y compilación lexicográfica que ha generado la obra de Shakespeare hasta nuestros días. Y es aquí, en la magnitud de la bibliografía existente, donde radica la dificultad de este método. Sin embargo, y a pesar de lo laborioso de esta tarea, este es el único camino para desbrozar y desentrañar el sentido de estos significados tan complejos que tanto el traductor en su labor creadora, como el traductólogo en su función evaluadora han de tener muy presentes.

Así pues, en este trabajo se pretende localizar y fijar todos aquellos términos y expresiones de carácter polivalente que embellecen el soneto XVI de Shakespeare para, acto seguido, llevar a cabo un cotejo entre el original isabelino y sus traducciones al español.

\section{ANÁLISIS TEXTUAL}

El juego verbal, tan profuso en toda la obra poética del dramaturgo isabelino, se hace especialmente patente en este poema. Constituye, sin duda, uno de los focos más potentes de connotaciones y efectos estilísticos, y al mismo tiempo, de dificultades traductológicas. A ello contribuye de manera significativa la armónica convivencia de toda una serie de imágenes con las variopintas asociaciones que liberan la ambigüedad y el doble significado en general. Imágenes como la de la mella del tiempo en la belleza del joven o de la trascendencia a través de la progenie y el arte ${ }^{3}$, se ven enriquecidas por la fuerza de la elección de un léxico marcado por la polisemia. Así, al lado del doble sentido de términos y expresiones como 'blessèd', 'barren', 'stand', 'top', 'hours', 'unset', 'virtuous', 'flowers', 'repair', 'give away yourself', y 'drawn', hallamos otros como 'gardens', y 'lines of life' cuyo significado es triple.

\subsection{Blessèd}

La forma 'blessèd' que aparece en el verso que cierra el primer cuarteto esconde una connotación que entronca perfectamente con esas imágenes de procreación en torno a la que

\footnotetext{
${ }^{3}$ A estas imágenes hacen referencia, seguramente, J. Grundy (1983)y M. Grivelet en sus respectivos artículos
} 
se articula no sólo este poema sino la totalidad de esa secuencia que componen los diecisiete primeros sonetos. Ese significado emerge, precisamente, de la imagen antitética que se configura en torno a la insuficiencia de la poesía para garantizar la perpetuación del joven destinatario del poema, de un lado, y de otro, la bendición inherente a la paternidad. En este sentido es muy atinada la observación de Kerrigan al afirmar que la idea de esterilidad que encierra 'barren' hace que salga a la luz el matiz de éxito, -incluso sexual - , de 'blessèd' ${ }^{4}$. De esta manera este autor matiza y completa la también acertada glosa de Tucker, para quien 'blessèd' equivalía a 'with success' (Tucker 1924: 93) y la de Evans (1996: 129), que profundiza aún más en el auténtico sentido del término: 'prosperous, happy (because you will be "blessed" with children, i.e. a living future')'. Esta lectura, por su coherencia en el entramado de la imaginería poética del soneto, resulta mucho más convincente que la que Schmidt hacía del término: 'happy, fortunate' (Schmidt 1971: 119).

\subsection{Barren}

En el adjetivo 'barren', en el cuarto verso del primer cuarteto, se perciben dos de los sentidos que el término poseía en la época y conserva aún hoy. Se trata en concreto de 'poor', 'arid' o 'dry' y 'bearing no children', 'without issue' o 'childless', como reza el $O E D$. En cuanto al segundo de esos sentidos, es decir, el estilísticamente marcado, se registra e ilustra con este ejemplo concreto, muy pronto, en el Shakespeare Lexicon and Quotation Dictionary de Schmidt como 'sterile'. Posteriormente, Foster repetirá la glosa de Schmidt si bien sin mencionar a este soneto (Foster 1969). Ingram y Redpath (1964: 38) explican el sentido de esta palabra relacionándola con la esterilidad que el poeta atribuye a sus propios versos: 'contrasting with the procreation theme "Verses beget nothing; you can beget a son"'. Wilson añade un matiz que aclara aún más el sentido y la función del término: 'The "barren" is not primarily intended, I think, as self-depreciative, but rather as unproductive' (Wilson 1963: 112). Booth y Kerrigan abundan, también, en esa imagen de esterilidad que encierra el término. Para Booth (1977: 159), en concreto, además de significar 'valueless' o 'worthless', equivale así mismo a 'incapable of bearing children'. Kerrigan, por su parte, pone también el acento en el hecho de que 'unlike wombs, my poems bear no children' (Kerrigan 1986: 194). Bevington glosa la palabra 'barren' como '(1) unable to produce offspring (2) poetically sterile' (Bevington 1997: 1667). Y, finalmente, Evans abunda igualmente en el valor doble de este término: '(1) fruitless verse (because it can bear no progeny); (2) poor, unattractive verse' (Evans 1996: 129).

\subsection{Stand, Top y Hours}

Los sentidos ocultos de 'stand', 'top' y 'hours', términos preñados de descaradas connotaciones sicalípticas, encierran una nota de reproche por la esterilidad de una vida un tanto disipada que es imprescindible mantener en la traducción so pena de renunciar a una rica gama de efectos estilísticos y calculados equívocos. El reproche es contra la actividad del joven que sacrifica el deber de la procreación en aras del placer sexual ilícito e infecundo. Así, la forma verbal 'stand' posee aquí además de su acepción más común la de

\footnotetext{
${ }^{4}$ Kerrigan (1986: 194) glosa la frase 'with means more blessèd' de este modo: '(1) through something more effectual (interpreting blessèd as "favoured with success"); (2) by breeding (allowing barren to evoke the sexual connotations of blessèd)'.

${ }^{5}$ El comentario de Burrow también incide en esos dos aspectos: blessèd continues the association between chidlbearing and happy good fortune established by (unbless 3.4)' (Burrow 2002: 412).
} 
'phallic erection' que es precisamente la lectura que Rubinstein hace de esta palabra en este soneto (Rubinstein 1984). Este uso del verbo 'stand' en el inglés isabelino aparece registrado y profusamente documentado en las obras lexicográficas más autorizadas así como en la crítica especializada: 'the erected yard' ${ }^{36}$, 'of the penis: to become or remain

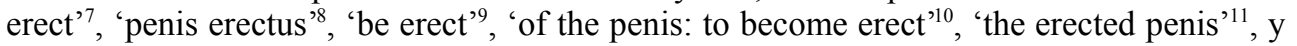
'of the penis: to be, or to become, erect' ${ }^{12}$. En cuanto al término 'top' Rubinstein, glosando precisamente este verso, lo interpreta como 'coitus' y se remite a lo que tanto el $O E D^{13}$ como Partridge (1968: 202) ${ }^{14}$, en su glosario, apuntan al respecto. Este carácter sicalíptico de 'top' aparece registrado y documentado también en otros trabajos de lexicografía y crítica especializada en el inglés isabelino ${ }^{15}$. Así, Foster define esta palabra como 'to copulate with' (Foster 1969); Colman la glosa como 'to copulate with (a woman)' [Colman 1974: 219]; Henke, por su parte, se refiere a 'top' del modo siguiente:

\footnotetext{
${ }^{6}$ Schmidt ilustra este sentido con las siguientes obras de Shakespeare: Sonnet 151.12; The Two Gentlemen of Verona II.i.90-1 y II.v.23; All's Well That Ends Well III.ii.43; The Taming of the Shrew Induction ii.127; Romeo and Juliet I.i.3 y II.i.25; y Macbeth II.iii.38 (Schmidt 1971).

${ }^{7}$ El Oxford English Dictionary (OED) cita este pasaje de la obra Choise of Valentines de Nashe: '"Unhappie me", quoth shee, "and wilt not stand? Com, lett me rubb and chafe it with my hand"'.

${ }^{8}$ Los ejemplos suministrados por Partridge (1968: 190) pertenecen a las obras The Two Gentlemen of Verona II. v.20-5, Romeo and Juliet II.i.25 y III.iii.28, y The Taming of the Shrew Induction ii..125 (1968: 190).

${ }^{9}$ Para Ellis existe un juego de palabras con este sentido de 'stand' enLove's Labour's Lost I.i.11 (1973: 98).

${ }^{10}$ Colman (1974: 215-6) añade a las obras mencionadas otro pasaje de Romeo and Juliet III.iii.89 y una cita de Troilus and Cressida I.ii.123 (1974: 215-6).

${ }^{11}$ Henke ilustra con la siguiente cita de Merry Passages and Jeasts (1630's) ese uso de 'stand' en el inglés isabelino: 'A Gentlewoman gave answere about something, she could not certainly resolve on; because says she, I know not how things may Stand betwixt me and my Husband. Standers by smiling at the worst sense, put her much out, and to the Blush' (Henke 1979: 254).

${ }^{12} \mathrm{El}$ comentario de Webb resume y recoge la mayoría de las citas mencionadas: Helo aquí: 'Of the penis: to be, or to become, erect - a common usage. Sometimes in word-play involving various idioms: "when itstands well with him, it stands well with her" Gent. II.v.20. (Lat. stare: "Dormis cum pueris...et not stat tibi, Galle, etc" Martial, III.LXXIII - "You sleep with boys who have active pricks, and Gallus, whatstands whith them doesn't stand with you" trans. Ker (Loeb). An Eliz. example may be noted in Roaring Girl, when a character declines to take a seat: "I had rather stand" "I know you had, good master Laxton [lack stone]" I.i.179. A common expr. is the standing of a case (a person's circumstance, a state of affairs, etc: Cymb. I.v.67), hence where the "case" is an innuendo of the female organ: "he is even in my mistress' case...stand, and you be a man (etc)". Rom. III.iii.84-8. The word "reason" by its sound suggests phallic uprising: "absent me from your bed. / I hope this reasonstands..." "Ay, it stands so that I may hardly tarry so long" Shrew, Ind. ii.121-3; "flesh stays no farther reason, / But rising ...to stand in thy affairs" Sonn. 151.8-12. Cf. also Tim. IV.iii.46; Troil. I.ii.122; Rom. II.i.25; Cymb. II.iii.70' (Webb 1989).

${ }^{13}$ El $O E D$ recoge y documenta ese sentido marcadamente sexual de la forma verbal 'top' con estas palabras: 'to "cover", copulate with'. Y, a continuación, lo ilustra con dos citas de Othello (III.iii.96 y V.ii.136) y una de Love's Sacr. (II.i, Oh, for three Barbary stone-horses to top three Flanders mares!) de Ford.

${ }^{14}$ He aquí la glosa de Partridge (1968: 202):: 'to coï with (a woman) in the commonest of all the "figures of Venus", the semantics being analogous to those of mount, ride (especially), leap, vault'.

${ }^{15}$ Tampoco habría que olvidar, a efectos traductológicos, la explicación que sobre este verso nos ofrece Padel pues si bien no incide en el aspecto sicalíptico de la palabra no por ello resulta menos pertinente en el contexto del soneto. He aquí la glosa de este autor: 'stand...on the top (w-p) are at your peak, are shown in the miniature ("this — time's pencil") as standing above the words — e.g. HORAE FELICES — on the frame' (Padel 1981: 161).A este respecto véase también la nota de J.D. Wilson (1963: 32).
} 
to cut off, to prune, to lop off the head of a flower, etc. (OED) - hence innuendo of to deflower sexually, i.e., to break the maidenhead; to copulate with a woman (PSB).Mirabel of De Gard, disguised as a lord, courting Oriana, '...that this bilbo-lord shall reap that maidenhead / That was my due; that he shall rig and top her!'WGC III.i.416-7 (Henke 1979: 224).

Finalmente, la explicación de Webb abunda también en ese sentido mencionado:

To cover; get on top, as the male animal upon the female. There may be an etymological link between 'top' and 'tup' - the copulative mounting by the ram - but this has not been established. The two uses in Sh. both occur in Oth., III.iii.400 and V.ii.139, and it may be that Iago is echoing the word that represents Othello and Desdemona as sheep in rut ('an old black ram / Is tupping your white ewe', I.i.89-90): 'Whould you ...Behold her topp'd'?; and so, Othello, deceived: 'Cassio did top her' (Webb 1989: 52).

Por lo que respecta al sustantivo 'hours', es nuevamente Rubinstein quien sugiere una interesante lectura que serviría de complemento perfecto a esos sentidos indecentes presentes, como se ha podido ver, en las formas 'stand' y 'top'. Esta autora, en concreto, asimila el sustantivo 'hours' en este soneto al término 'whores' y ofrece un extenso y rico comentario del primero de estos términos:

A whore (L; cf. CE, IV.ii.53; MWW, II.ii.38). Horel: a fornicator; horal: 1600s, hourly. $A Y L$, II.vii.26. A fool 'dreew a dial from his poke' and looking at it said, 'And so, from hour to hour, we ripe and ripe,/ And then, from hour to hour, we rot and rot; / And thereby hangs a tale' - the general decay of man from hour to hour, and the rot of disease as man goes from whore to whore on the RIPE of the Bankside, home of the stews. Perh. a pun on the common inscription on old church dials and clocks: Vulnerant omnes, ultima necat 'All [hours] wound, the last [one] kills'. The tale that hangs could be a diseased, impotent penis (C). See SAKE, Oth, for a similar tale or penis (C;P).KJ, III.i.56: 'Fortune, O...She adulterates hourly with thine uncle John...That strumpet Fortune, that usurping John!' The strumpet adulterates (commits adultery) hourly or horal, like the horel or fornicator she is.

Ham, III.ii.135:

Hamlet. ...look you, how cheerfully my mother looks, and my father died within these two hours.

Ophelia Nay, 'tis twice two months, my lord.

His father died within these two hours or between (the action of) these two whores, his mother and his uncle ('He that hath kill'd my king and whored my mother' - V.ii.64). Hamlet's inaccuracy reflects not only his perception of his mother's too-speedy re-entry into marriage, as usually annotated, but also his perception of the nature of the marriage, his feeling she and the King are two adulterous whores, who, between them, killed the former king. See TWO HOURS.

$A W$,IV.iii.35. His friends do not expect Bertram 'till after midnight; for he is dieted to his hour'. He will be with his whore, the young lady he 'perverted' till after MIDNIGHT (hour of phallic erection). He 'fleshes his will [sexual ingression - $\mathrm{P}$ ] in the spoil of her hounour'. 'Spoil' quibbles on flesh, spoiled, and the diet (cure for VD: see RHEUM) [Rubinstein 1984: 129-30].

El $O E D$ recoge y documenta la fluctuación de las grafías de los sustantivos hour y whore entre los siglos XIV y XVI, fluctuación que permitió durante todo ese período, al menos, la intercambiabilidad de ambas $y$, por lo tanto, que se prestasen a una continua 
confusión ${ }^{16}$. En su conocido estudio sobre la pronunciación en la obra de Shakespeare Kökeritz no sólo recoge la semejanza existente entre esos dos términos sino que, además, propone varios ejemplos de obras de este autor en los que estas palabras propician el mismo tipo de juego verbal que en este soneto ${ }^{17}$. He aquí la glosa de Kökeritz:

A clever pun on hour and whore occurs in AYL 2.7.26 ff, where Jaques laughingly quotes Touchstone:

And so from houre to houre, we ripe, and ripe,

And then from houre to houre, we rot, and rot,

And thereby hangs a tale.

This passage has two subsudiary puns, tale-tail and ripe-ripe (see below).

The same pun is used in CE 4.2.53 ff.:

DROMIO...'tis time that I were gone:

It was two ere I left him, and now the clocke strikes one.

ADRIANA. The houres come backe, that did I never here.

DROMIO. Oh yes, if any houre meet a Serjeant, a tunes backe for verie feare.

ADRIANA. As if time were in debt: how fondly do'st thou reason?

DROMIO. Time is a verie bankerout, and owes more then he's worth to season.

Nay, he's a theefe too: have you not heard men say,

That time comes stealing on by night and day?

If $I$ be in debt and theft, and a Serjeant in the way,

Hath he not reason to turne backe an houre in a day?

In MWW 2.2.38 ff. Falstaff chooses to interpret Mrs. Quickly in his own way:

HOSTESS. Ile be sworne,

As my mother was the first houre I was borne.

FALSTAFF. I doe beleeve the swearer.

Very likely the same pun is intended in MA 1.1.276 (Kökeritz 1960: 117-118, 248 y 308).

La riqueza significativa de estos versos — si se consideran válidos todos los matices comentados - plantea, sin duda alguna, un serio problema a cualquiera que se acerque a este soneto con ánimo de verterlo fielmente a otra lengua. Sin embargo, si se pretende que el texto en la lengua de llegada sea un reflejo cabal del texto de partida parece lógico exigir del traductor un esfuerzo mayor para conservar no sólo ese sentido que se manifiesta en la superficie sino también los matices escondidos que muestran una relación mucho menos idílica, entre el sujeto poético y el joven agraciado, de lo que, a simple vista, pudiera parecer.

\subsection{Gardens}

Una vez más el autor de estos poemas echa mano de ciertas imágenes del mundo de la botánica para tratar de vencer la renuencia del 'fair young' a procrear o, por decirlo de otro

\footnotetext{
${ }^{16}$ En efecto, ambos términos coexistieron a lo largo de estos siglos compartiendo las grafíashore, howr (e, houre. A este respecto, véase el $O E D$ en las entradas correspondientes a hour y whore.

${ }^{17}$ Fabricius sugiere la existencia de ese mismo retruécano en 2HIV IV.i.54-6 (Fabricius 1994: 229).
} 
modo, a engendrar un heredero que perpetúe su linaje. En esta ocasión el sustantivo 'gardens' no sólo da pie a una muy lograda metáfora sino que además posee un valor oculto - órgano femenino de la generación - que la crítica le ha reconocido aquí y que el traductor debería conservar en la lengua de llegada ${ }^{18}$. Este significado escondido del término forma parte, sin lugar a dudas, de ese subtexto cargado de ironía y procacidad que impregna todo el poema y que no es sino una muestra más del estilo peculiar del autor isabelino. Tanto la crítica como la lexicografía especializada en la obra de Shakespeare o bien pasan por alto o bien no aprecian el equívoco que dimana de la dualidad léxica de 'gardens'19. Mención aparte, no obstante, merecen tanto la nota de Pooler como los comentarios de Rubinstein y Pequigney. En efecto, en los comentarios de estos críticos se percibe - de manera especialmente clara en los de Rubinstein y Pequigney - el interesante retruécano al que se presta ese sustantivo. De la glosa de Pooler se infiere, sin embargo, no sólo su erudita preparación y cuidado exquisito al tratar un tema ciertamente escabroso sino también, y lo que parece más importante, el acierto en la detección del sentido oculto de 'gardens': 'jardinet is similarly used by Villon' (Pooler 1931: 19). Este poeta francés del siglo XV en su obra Le Testament incluye la historia de 'La vieille en regrettant le temps de sa jeunesse' donde, en el huitain LIII, se describe el cuerpo de la mujer bajo estos términos:

Ces gentes espaulles menues,

Ces bras longs et ces mains traictisses,

Petiz tetins, hanches charnues,

Eslevees, propres, faictisses

A tenir amoureuses lisses;

Ces larges rains, ce sadinet

Assis sur grosses fermes cuisses,

Dedens son petit jardinet? (Villon 1972: 87)

Rubinstein, por su parte, ofrece una precisa y detallada glosa del sentido lascivo de 'gardens' en el inglés isabelino y entre los diversos ejemplos con los que lo ilustra cita precisamente a este soneto:

Female pudendum. Hortus: privy parts of a woman (Nathan Bailey, English Dictionary, 1728); L hortus: a garden. Boccaccio (Decameron) p. 136: 'I'll work your garden [l'orto] in a way it was never worked before', says a virile boy who works for the convent. Cotton, 'Forbidden Fruit': 'the bliss that I would tast, / Is something lower than the wast, / And in yar Garden's Centre plact' (Penguin Book of Restoration Verse, p. 176). Song Sol 4:12: 'A garden inclosed is my sister, my spouse; a spring shut up, a fountain sealed'; 4:16: 'Let my beloved come into his garden, and eat his pleasant fruits'. Oth, I.iii.323, Iago: 'Virtue! a fig! 'tis in ourselves that we are thus or thus. Our bodies are our gardens, to the which our wills

\footnotetext{
${ }^{18}$ Durrant destaca, precisamente, el tono de marcado corte sexual con el que algunos términos del mundo de la botánica, y entre ellos 'gardens', se proyectan en la poesía occidental: 'The association of bowers, gardens, and valleys with sexuality is traditional in Western poetry, and Wordsworth himself makes use of it in a poem written at the age of sixteen' (Durrant 1969: 10).

${ }^{19}$ Las definiciones que se encuentran en las principales obras lexicográficas hacen referencia tan sólo al sentido superficial del término. Así, para Schmidt 'garden' es 'a piece of ground planted with herbs, flowers or fruit-trees, or laid out for pleasure'. La explicación del $O E D$ es muy similar: 'An enclosed piece of ground devoted to the cultivation of flowers, fruit, or vegetables'. Por extraño que parezca, tampoco en las ediciones más autorizadas se hace alusión al valor bisémico de este término. La obra de Williams, sin embargo, representa un caso aparte pues si bien no se menciona ni este soneto ni ningún otro trabajo de Shakespeare ilustra profusamente con citas de obras de la época el sentido sexual de esta palabra (Williams 1994).
} 
are gardeners'. The will is the penis $(\mathrm{C} ; \mathrm{P})$. This subtle pun links virtue, fig and garden - the fig-leaf that covers both the garden and the will after the loss of virtue in the original Garden of Eden.

Son. 16 Sh advocates that his friend defy immortality through posterity: 'Now stand you on the top of happy hours, / And many maiden gardens, yet unset / With virtuous wish would bear your living flowers' He does stand (with phallic erection $-\mathrm{C}$; P) on top (coitus $O E D ; \mathrm{P}$ ) of happy HOURS / whores, instead of virtuous maidens, with unset virginal gardens (Rubinstein 1984: 108) ${ }^{20}$.

Pequigney, finalmente, en una nota a pie de página, completa y complementa el interesante comentario que sobre este mismo término hiciera Rubinstein con anterioridad:

Under the entry 'garden', John S. Farmer and W.E. Henley give the following: '(venery) the female pudendum', and cite Sonnet 16. See theirSlang and Its Analogues, Past and Present (7 vols., 1809-1904; rpt., New York: Kraus Reprint Corporation, 1965). Eric Patridge gives that definition too, dating the usage from the sixteenth to the present century, in The Macmillan Dictionary of Historical Slang (New York: Macmillan, 1974). According to Freud, 'gardens are common symbols of the female genitals' in dreams ("Symbolism in Dreams", Introductory Lectures on Psychoanaysis, in The Standard Edition of the Complete Psychological Works, ed. James Strachey [London: Hogarth Press, 1965], 15: 159) [Pequigney 1985: 227].

\subsection{Unset}

Esta acepción que relaciona 'gardens' con los órganos sexuales femeninos posibilita una nueva interpretación del término 'unset'. En efecto, en esta palabra se contiene no sólo su sentido más común de 'unplanted'21, 'not furnished with plants' (OED), 'not planted' (Reed 1923: 8), 'as we "set" a plant' (Tucker 1924: 93), 'not yet planted' (Padel 1981: 161) sino también ese otro the 'unsown' que, como puede verse con facilidad, conecta perfectamente con esa imagen de la sexualidad y la procreación presente en todo el soneto. Onions, en concreto, en su conocido glosario, recoge ya esta doble lectura mencionada: "not planted or sown' (Onions 1986). Posteriormente, Seymour-Smith incide también en esa dualidad léxica de la forma 'unset' en este soneto al glosarla precisamente como 'unsown' (SeymourSmith 1963: 123). La explicación de Ingram y Redpath, así como la de Evans, abunda asimismo en el sentido indicado. Ingram y Redpath manifiestan lo siguiente con respecto a esta palabra: ""not planted", or, more appropriately here, "not sown with seed". The latter use was current (see Cotgrave and $O E D$ )' (Ingram y Redpath 1964: 38). Evans, por su parte, propone una lectura muy similar: 'virgins (metaphorically described as potential "gardens") as yet unseeded or unplanted ("unset")' (Evans 1996: 129). Finalmente, Bevington también reconoce esa imagen de la procreación presente en este término y que este autor interpreta como 'unimpregnated' (Bevington 1997: 1667).

\subsection{Virtuous}

El carácter polisémico del adjetivo 'virtuous', en el tercer verso del segundo cuarteto, puede suponer un serio escollo a la hora de verterlo al español. En efecto, en esta palabra se

\footnotetext{
${ }^{20}$ Véase asimismo el comentario de esta autora en torno a esta misma palabra en su artículo sobre el simbolismo sexual en Shakespeare y Freud (Rubinstein 1988: 1-26).

${ }^{21}$ Así han glosado el término Schmidt (1971: 1292), Burto (1964: 56), Booth (1977: 159), Kerrigan (1986: 194) y Bevington (1997: 1667)
} 
concentran tanto ese concepto propio de aquellos que se ejercitan en la virtud y obran según ella como esa noción de la persona que se abstiene de todo goce sexual, o se atiene a lo que se considera como lícito. La fuerza expresiva de este término no se agota, sin embargo, en los sentidos mencionados pues, según nos recuerdan Ingram y Redpath, la imagen de la fertilidad parece asomarse también en este caso concreto. En el $O E D$ se recogen y documentan, en el inglés de la época, cada uno de los significados que el adjetivo 'virtuous' posee aquí: 'Possessing or showing virtue in life and conduct; acting with moral rectitude or in conformity with moral laws', 'Of women. Chaste' y 'Producing or capable of producing, (great) effect; powerful, potent, strong ${ }^{22}$. En cuanto a la crítica en general tan solo unos pocos autores de edición reconocen en este poema los sentidos más arriba mencionados si bien no todos ellos observan todos y cada uno de dichos significados en el soneto. Así, Ingram y Redpath parafrasean este verso con estas palabras: 'would be only too glad to bear you children, in wedlock'. Posteriormente, y refiriéndose concretamente al adjetivo 'virtuous' dicen lo siguiente: '"Virtuous" may possibly also carry the secondary sense of fertility' (Ingram y Redpath 1964: 38) ${ }^{23}$. En el glosario de Partridge, por otro lado, se ilustra con una cita de lHenry VI ese otro sentido de casto que, como se ha visto, posee también 'virtuous'. Más tarde, tanto en la edición de Kerrigan como en la de Evans se atribuye ese mismo significado a este término en este soneto concreto. Así, Kerrigan hace una paráfrasis del verso siete con estas palabras: 'would willingly but chastely bear your children' (Kerrigan 1986:194). Por su parte, Evans lo glosa de este modo: '(1) chaste; (2) morally right (both meanings with reference to the married state)' (Evans 1996: 129).

\subsection{Flowers}

La metáfora que atesora 'flowers' y que corona el tercer verso del segundo cuarteto se suma también a ese tropo de la procreación que bajo formas muy diversas impregna estos sonetos. En efecto, la mayor parte de los críticos y autores de edición coinciden en que el sentido figurado de 'flowers' no es otro que la progenie. Sin embargo, la gama de significados del término en este poema no se agota ahí pues, como nos recuerda Ray, en la época isabelina 'flowers' equivalía también, por lo menos, a poemas y versos:

Shakespeare, then, employs in Sonnet 16 a sense of 'flowers' which was quite common in his own day. In addition to denoting rhetorical embellishments in poetry, 'flowers' had been extended in the sixteenth Century to refer to poems themselves (Ray 1979: 24-5).

De esta suerte, los traductores deben enfrentarse, de nuevo, a un término que, a causa de la polisemia, dificulta sobremanera su labor. No obstante, si quieren ser fieles al texto de partida deben conservar todas las connotaciones que la forma 'flowers' posee en el poema original.

\subsection{Lines of Life}

El sintagma nominal 'lines of life', que ocupa un lugar prominente en el primer verso del sexteto, posee una rica gama de connotaciones y matices que lo configuran como uno de

\footnotetext{
22 Schmidt define el adjetivo 'virtuous' en este poema como 'morally good'.

${ }^{23}$ Ambos autores consideran, además, que el uso de la palabra 'virtue' con el sentido de 'power' es muy frecuente en Shakespeare. Esa imagen de fertilidad que, según estos autores, se desprende del adjetivo 'virtuous' permite aventurar una nueva interpretación de la forma verbal 'bear' que, a su sentido primario de 'to carry', sumaría ese otro de 'to give birth to'.
} 
los centros significativos del poema ${ }^{24}$. En efecto, las diversas imágenes esparcidas a lo largo del soneto se ven reflejadas en los múltiples sentidos que conforman el núcleo semántico del término line. Esa riqueza léxica no pasa desapercibida a los atentos ojos de críticos y lexicógrafos del dramaturgo isabelino que, de forma especialmente unánime, reconocen y glosan el juego verbal aquí presente. De todos ellos, tal vez sean Ingram y Redpath quienes ofrezcan la interpretación más detallada y exhaustiva de este sintagma ${ }^{25}$. Estos autores inician su extensa explicación con la enumeración de las múltiples interpretaciones que tanto críticos como los autores de edición más autorizados han realizado a lo largo de los siglos XVIII, XIX y XX y finalizan su prolijo comentario señalando esas acepciones que, según su criterio, se perfilan como las más pertinentes en el soneto. He aquí sus palabras:

A phrase that has proved fertile of comment. The following list contains the most noteworthy interpretations with the names of their earliest and / or chief advocates: a) children (as 'living pictures') (Malone, who conjectured 'lives' for 'lines'); b) lines drawn with a pencil - a portrait (Schmidt, Dowden, Empson); c) lineage, descendants (Dowden, Tyler, Beeching, Empson); d) wrinkles on the brow of age (Tyler, who later rejected it for (c), Empson); e) (from palmistry) marriage and procreation (Wyndham, Empson); f) form of personal appearance in the young men...or in his descendants (as one speaks of the lines of someone's figure) (Pooler, Empson); g) lines drawn with a pen in writing (Alden, Dowden, Empson); h) lines of verse ('the kind a sonnet has fourteen of') (Wyndham, Empson); i) lines of relationship in a genealogical table (Fort); j) 'the line fixed in the continuum with which space-time theorists describe such reality as they allow to a particle' (Empson). It seems reasonable to hold with Professor Empson that there is a play here on several simultaneous connotations, and that the quality of the poem would be impaired if we confined our interpretation to a single association. But some selection and priorities would seem possible. We take it that 'lines of life' is the subject, and 'that' a demonstrative adjective, and that 'of life' bears the emphasis, and is intended to contrast the living portrait (the child) with the inanimate products of the 'pencil' or the 'pen'. This interpretation would seem to give highest

${ }^{24}$ William Empson (1950: 76-8), en su conocida obra Seven Types of Ambiguity, hace un interesante análisis de este soneto.

${ }^{25}$ Entre los críticos y autores de edición anteriores a la publicación de la obra de Ingram y Redpath que hacen mención del sintagma 'lines of life' cabe citar a los siguientes: Beeching ('Living lineage, i.e. children; with a play on the word as used of an artist's "pencil" and a poet's "pen"') [1904: 85], Reed ('children') [1923: 8], Tucker ("life" is emphatic. The "lines" drawn by a portrait painter, or the "lines" written by a poet, are inferior to the "lines" of life, i.e. the lineaments which portray him in a living child. The play on the word is frequent [18.12, 19.10, etc.]; cf. Cymb. IV.i.20 "The lines of my body are as well drawn as his "') [1924: 93], Tucker Brooke (1936: 251), Lever [1956: 56] ('Line 10 of sonnet XVI, given in the Quarto as Which this [Times pencil] or my pupil pen

clearly requires emendation. A misplaced comma after "pencil", into parentheses which confuse the entire meaning of the image. The line should be read as it must have stood in manuscript:

Which, this time's pencil, or my pupil pen, ...

"This time's pencil" thus refers to a portrait, or "painted counterfeit" of the Friend, representing the best art of the present age [an idea which is further developed figuratively in XXIV]. In contrast is the Poet's, "pupil pen": but the lines of portraiture and verse are both inferior to the "lines of life". This play on "lines" for features and writing had already been made in Sidney's "Who will in fairest booke of Nature" [Astrophel and Stella, LXXI]:

Let him but learn of Love to reade in thee

Stella, those faire lines, which true goodnesse show!') [1956: 56],

Seymour-Smith [1963: 123] ("living lines": i.e. drawn by Nature, as opposed to those of a portrait, or the lines of Shakespeare's poems [cf. 1.4]. There is also a play on the "line of life" in palmistry: this is supposed to reveal prospects of marriage and children') [1963: 123]; y Burto ('lineal descendants') [1964: 56]. 
priority to senses (a) and (c), and somewhat lower priority to (f), (e), and (i), in that order (Ingram y Redpath 1964: 38-9).

Esta extensa y atinada glosa de Ingram y Redpath contiene, si no todas, la gran mayoría de las posibilidades significativas que este sintagma desarrolla en el soneto. La crítica posterior a estos autores de edición no añade matices nuevos a los enumerados anteriormente y se limita, en general, a destacar, como más obvios, algunos de esos sentidos. En concreto, Wilson, citando a Alden, señala como posibles las acepciones de ese término que hacen referencia al linaje y a la representación pictórica del joven agraciado así como a los versos del sujeto poético. Y añade, esta vez refiriéndose a Dowden, que también se podría entender aquí el sentido de 'eternal lines':

Playfully applicable both to lineage and the lines drawn by artist and poet (Alden). But D. thinks it refers also to the 'eternal lines' which form the climax of 18. This seems more likely and if correct would link 18 with 15, 16 and 17 (Wilson 1969: 113).

La interpretación de Booth se centra exclusivamente en la explicación de un posible juego homofónico entre los términos loins (con el significado de hijos) y 'lines' que complicaría bastante la de por sí difícil labor del traductor. He aquí el comentario de este autor:

Godshalk suggests ' a pun on "loins of life" with suggestions of copulation, pregnancy, and birth...I heard the same pun in 74.3: "My life hath in this line some interest", and I was shocked by the bawdy potential of 86.13 ["But when your countenance filled up his line"]'. Kökeritz (pp. 125, 217) argues that the two words were homonyms; OED gives 'to loin' as a variant of 'to line' ('to cover on the inside', 'to stuff', 'to copulate with'), and gives this example from 1587: 'The Indians, who tie their sault bitches often in woods, that they might be loined by tigers'. For 'loins' as the seat of generative power and 'loin' meaning 'offspring', 'descendants', see $O E D$, s.v. 'loin', sb., 2.b. Godshalk notes that Ellis (pp. 156-7) finds the 'lines / loins' pun in $L L L$ IV.iii.55 and $R \& J$ I. Prologue 5. The phonetic likeness of line and 'loin' may also have enhanced the play on two senses of 'to line' in AYLI III.ii.95-6: 'Winter garments must be lin'd, / So must slender Rosalinde' (Booth 1977: 579).

Padel, que señala la existencia de un juego verbal en este sintagma, y Kerrigan recogen algunos de los sentidos presentes en el comentario de Ingram y Redpath. El primero parafrasea estas palabras como 'living reality, lines of personal descent, lines of form'(Padel 1981: 161). Por su parte, Kerrigan abunda también en alguno de los sentidos mencionados:

(1) lineage (with a suggestion of the lines used on genealogical charts to show descent); (2) ofspring (vital, not merely painted, portraits of the youg man's living outline, the form of the youth reborn in his children); (3) lines on the hand (examined by palmists to judge life expectancy, extrapolated here by lineage and offspring) [Kerrigan 1986: 194].

Barber vuelve a recordar las numerosas interpretaciones que del sintagma 'lines of life' se han ofrecido hasta ahora aunque él personalmente se decante por esa imagen en la que los hijos aparecen como el reflejo más logrado de los rasgos físicos de sus padres:

A case in point, which also will be of interest to us in considering the relationship of Shakespeare to the friend he addresses, comes in Sonnet 16, where the poet urges that children can provide reproductions of the friend 'much liker than your painted counterfeit', and then goes on with an extraordinarily rich use of the word 'lines':

So should the lines of life that life repair, 
Which this Time's pencil or my pupil pen,

Neither in inward worth not outward fair,

Can make you live yourself in eyes of men.

The suggestiveness of 'lines of life' appears in the variety of commentator's paraphrases recorded in the Variorum edition: the 'lines of life' can be the lines life etches on a face, or the lines of descent in a genealogy or the lines of the living pictures presented by children, or the lines of children as living poems (as opposed to the mere written lines of the 'pupil pen') or even perhaps, as an echo at the back of the mind, what one commentator defends in urging unconvincingly that 'lines of life' is a misprint for 'loins of life' (compare the sonnet's conclusion: 'And you must live, drawn by your own sweet skill') [Barber 1987: 12-3].

Vendler aprecia un posible juego verbal entre los sustantivos 'lines' y 'loins': 'The biological lines of life (perhaps with a pun on loins, probably pronounced as "lines") in sexual conjunction will repair the young man's mortal life' (Vendler 1997: 114). Por último, Evans, al igual que algunos autores anteriores, se limita a enumerar algunas de las diversas posibilidades significativas de 'lines of life' enunciadas con anterioridad por Ingram y Redpath:

Lines of life. The phrase has caused much debate (see summary of interpretations in Ingram and Redpath): (1) lineage; (2) descendants (children and children's children; compareRom. 3.5.180); (3) lines drawn with a pencil (in a painting) or pen (in verse writing); (4) lines in a genealogical table; (5) lines of a person's figure; (6) life-lines in the palms (palmistry). Of these, (1) and (2) would appear to be primary (Evans 1996: 129).

Como se puede deducir de las numerosas interpretaciones recogidas en este análisis la riqueza semántica del sintagma 'lines of life' se configura como su rasgo más acusado. Se podría, pues, pensar que nos encontramos ante una de esas formas que presenta una gran resistencia a la traducción e incluso cabría calificarla como un intraducible. Sin embargo, y a pesar de la gran dificultad que supone conservar todos estos sentidos en la lengua de llegada, no se debe negar la posibilidad de alcanzar una solución al problema pues la maleabilidad de la lengua, como hemos podido observar en algunos casos, ofrece recursos casi ilimitados.

\subsection{Repair}

En el término 'repair', que culmina el primer verso del tercer cuarteto, se aprecia, una vez más, ese juego homofónico que se basa en la asociación un tanto macarrónica del verbo inglés repair y la forma repère y cuya nueva aportación semántica al verso se podría traducir como 'ser padre o ser padre de nuevo'. De los lexicógrafos, críticos y autores de edición consultados tan solo Booth - como sucede en los casos de los sonetos tres y diez - menciona este curioso juego léxico y, para una mejor comprensión de este interesante escollo, se remite a la explicación que aparece en el soneto tres de esta misma secuencia. Los comentarios que ofrece el resto de la crítica se asemejan entre sí aunque ninguno se aproxima a las observaciones que sobre esta palabra vierte Booth ${ }^{26}$.

${ }^{26}$ Tucker se inclina por 'keep in good repair' (1924: 93); Seymour-Smith utiliza la forma 'preserve' como sinónimo de 'repair' (1963: 123); Padel emplea como homólogo de este término una de las formas que registra Onions, a saber, 'renew' (1981: 161) y Duncan-Jones lo glosa como 'restore; renew; replicate you to the life' 


\subsection{Keeps y To Give Away Yourself}

El sentido de 'keeps', que es el núcleo verbal del primer verso del pareado final, produce un retruécano con el sintagma que le precede que, por sus efectos estilísticos, es necesario mantener en la traducción ${ }^{27}$. Por su parte, el sintagma 'to give away yourself' además del contraste semántico que genera su significado superficial en yuxtaposición con

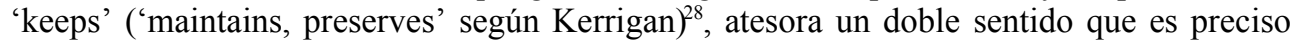
establecer. En efecto, con esas palabras el sujeto poético no sólo insta una vez más al joven agraciado a contraer matrimonio, sino también, y al mismo tiempo, a perpetuarse. Todo ello gracias a que, como ya explicara Malone a finales del siglo dieciocho (Ingram y Redpath 1964:40), bajo el significado más obvio de 'to give away yourself' (es decir, el de contraer matrimonio) subyace otro más sutil relacionado con la idea de la procreación. Esta anotación se repetirá posteriormente en las ediciones más fiables. Reed (1923: 8) y Burto (1964:56), por ejemplo, señalan el sentido marcado de la frase ('to beget children'). También reconocen esa connotación del término, como se ha visto más arriba, Ingram y Redpath así como Wilson ('to produce likenesses of yourself') [Wilson 1969: 113]. Booth, por su parte, lo glosa como 'transfer yourself into children' (Booth 1977:159). Padel explica el sintagma 'give away' como 'pass on (to offspring)' (Padel 1981:161). Y, por último, tanto Kerrigan ('to your children') [Kerrigan 1986:194] como Dodsworth ('in marriage or in your children') [1995:11] y Bevington ('marry and beget children') (Bevington 1997: 1667) abundan también en este significado.

\subsection{Drawn}

Finalmente, en el último verso del soneto el juego verbal que surge en torno al doble sentido del participio pasado 'drawn' pone de manifiesto y resume con gran maestría el argumento del poema: ni la pluma ni las más bellas de las pinceladas son suficientes para derrotar al tiempo destructor; sólo se le puede vencer a través de la descendencia. En efecto, en el término 'drawn' confluyen varios significados, muy en consonancia todos ellos con el sentido global del poema. Por ejemplo, se adaptan perfectamente al contexto dos de las acepciones que, según el $O E D$, poseía ya el verbo draw en la época, a saber, 'prolong' y 'delineate'. Esta es, en concreto, la doble lectura que hacen Ingram y Redpath en su edición de la obra ${ }^{29}$. Booth va más lejos al sugerir una probable asociación fálica entre este término y los instrumentos de la escritura referidos en el verso décimo:

Shakespeare may be playing on the likeness of shape between the phallus - the instrument by which the young man will draw living pictures (and draw out, continue, the length of his life) — and the artist's instruments mentioned in line 10 (Booth 1977: 159 ${ }^{0}$.

(1997: 142).

${ }^{27}$ Así lo han visto Padel (1981: 161) y Kerrigan (1986: 194).

${ }^{28}$ Evans (1996: 129) explica la frase 'keeps yourself still' del modo siguiente: 'preserves "you" (inner and outer) (1) without change, (2) always. Compare Donne, "The Canonization", 26-7: "Wee dye (i.e. at orgasm) and rise the same, and prove / Mysterious by this live"'.

${ }^{29}$ He aquí el comentario de estos autores: “(1) "delineated" (in the "living pictures"); and, just possibly, though doubtfully, (2) "continued", "prolonged" (cf. "drawn out")’ [Ingran y Redpath 1964: 40].

${ }^{30}$ Kerrigan, por su parte, abunda asimismo en las ideas mencionadas. He aquí la glosa que hace de todo el verso: "Various emphases are possible: "if you want to survive, you must do so through your sexual artistry, not through my verse or other men's painting"; "you have a positive obligation to live by breeding yourself"; "if you produce children you will definitely live after your death". The penis, mightier than the word, replaces thepencil and pen 


\section{COTEJO TRADUCTOLÓGICO}

Comprobemos ahora la respuesta de los traductores ante esta riqueza verbal del texto isabelino.

\subsection{Blessèd y Barren}

En concreto, los diversos sentidos que confluyen en los términos 'blessèd' y 'barren', en el último verso del primer cuarteto, no deberían ser un obstáculo a la hora de verterlos al español por cuanto que los términos bendecir y estéril se pueden utilizar de un modo similar. No obstante, por lo que respecta a la palabra 'blessèd' tan sólo García Calvo y Méndez Herrera han optado por el verbo bendecir con lo que sólo en sus textos se reflejan las imágenes de la felicidad y de la prosperidad, esta última referida especialmente al fruto de la unión matrimonial o la descendencia. En cuanto a las fórmulas utilizadas por el resto de los traductores, según se acaba de apuntar, en ninguna se reproducen con fidelidad los sentidos mencionados.

Por lo que atañe al término 'barren' la respuesta de los traductores, en general, ha sido sensiblemente mejor. En concreto, las versiones de Astrana Marín, Mujica Láinez, Fátima Auad y Mañé Garzón, Méndez Herrera y Sordo, al emplear el adjetivo estéril, recrean, a la vez, la alusión a la aridez y la imagen de la fertilidad. De un modo similar hay que entender las fórmulas utilizadas por Vedia y García Calvo ('vano'), Pujol ('baldíos') y Falaquera ('baldías'). Finalmente, en los textos de Dieste, Damians de Bulart, Acuña, Pérez Romero, Montezanti, Álvarez y Gómez Gil no se aprecia esa doble alusión con lo que estos autores se apartan del sentido cabal del texto original.

\subsection{Stand, Top y Hours}

En cuanto a la forma 'stand' en la que, como se recordará, la crítica especializada detectaba una fuerte inclinación hacia lo procaz — pues puede aludir en este contexto al estado de erección del miembro viril-, en ninguna de las versiones parece vislumbrarse tan siquiera esta sugerencia. En concreto, la mayor parte de los traductores se inclina por el sentido más común de 'stand', es decir, el de permanecer o estar de pie², con lo que se pierde el matiz aludido.

Tampoco consiguen los traductores reproducir en español esa alusión a la realización del acto carnal que, como ya se ha dicho, la crítica percibía en el término 'top'; y, en el caso de alguno de ellos, es una auténtica lástima, ya que se sirven de unas fórmulas que ponen el texto al borde de una ambigüedad sexual análoga. Así, si Dieste, Damians de Bulart, García Calvo, Fátima Auad y Mañé Garzón, Méndez Herrera, Pérez Romero, Falaquera y Gómez Gil - que traducen el segmento 'on the top of happy hours' por 'en la cima de tus felices horas', 'Pues hoy vives tus horas más dichosas', 'Hoy en la cumbre estás de las horas mejores', 'Estáis ahora en la cúspide de las horas felices', 'Te alzas de horas felices en la

of lines 10-12; see Gratiano's explicit "I'll mar the young clerk's pen" atThe Merchant of Venice V.i.237' (op. cit., p. 194). Evans también hace hincapié en ese sentido sicalíptico de 'drawn' en este soneto: 'i.e. you will be your own painter or poet (with a sexual suggestion, since both "pencil" and "pen" were slang terms for "penis"; compare Rom. 1.2.39). Influenced perhaps by Sidney, Arcadia (1593), p. 74: "With his sweet skill my skillesse youth he drewe"' (Kerrigan 1986: 129).

31 Este es el caso de las expresiones 'estás' (Mújica Láinez, García Calvo, Sordo, Pujol y Falaquera), 'estáis' (Fátima Auad y Mañé Garzón), 'os halláis’ (Astrana Marín), ‘te alzas’ (Méndez Herrera), 'te yergues' (Pérez Romero) y 'vives' (Damians de Bulart). 
cima', 'Te yergues de felices horas en esa cima', 'Ahora estás en la cima de las horas felices' y 'Ahora te hallas en la cumbre de las felices horas', respectivamente-, hubiesen vertido el término 'hours' por hora o momento (en singular), habrían conseguido, sin duda alguna, una alusión soterrada al clímax del acto sexual. En ese equívoco hubieran quedado integradas, en cierto modo, la alusión carnal de 'top' y el doble sentido que por razones homofónicas tiene 'hours' (whores).

'Hours', término de muy difícil traducción, precisamente por la ambigüedad que se acaba de señalar, no corre mejor suerte en las versiones analizadas. En efecto, ni el sustantivo 'horas ${ }^{32} \mathrm{ni}$ ' días ${ }^{33}$, términos que eligen los traductores, encierran, en el contexto en el que se utilizan, sugerencia alguna relacionada con la prostitución. Acuña omite el término con lo que su versión se aleja más del texto de partida.

\subsection{Gardens y Unset}

La asociación de 'gardens' con las partes pudendas de la mujer, que entra en perfecta sintonía subtextual con los sentidos soterrados de los términos anteriores, se mantiene en su integridad en los textos españoles ya que los traductores se sirven del término jardín/es o huerto/s que, en el contexto en que se utilizan, poseen unas connotaciones idénticas. De nuevo la versión de Acuña es la que se distancia más del original al no traducir el término inglés.

En cuanto a esa imagen relacionada con la procreación que atesora 'unset' la respuesta de los traductores es, por lo general, bastante atinada. En concreto, estos se sirven de términos como 'por cultivar' (Astrana Marín), 'sin cultura' (Vedia), 'incultos' (Mujica Láinez y García Calvo), 'sin cultivar' (Fátima Auad y Mañé Garzón), 'por cultivar' (Falaquera), 'no roturado' (Pérez Romero), 'sin cultivo' (Montezanti), 'intacto' (Pujol), 'selvático' (Álvarez) y 'vírgenes de cultivo' (Gómez Gil) que, según se puede apreciar, poseen un sentido muy similar. En las restantes versiones o se utiliza un término que no responde a estos sentidos o se soslaya el problema refundiendo en una frase, tampoco adecuada, parte del verso en que aparece 'unset' y del siguiente.

\subsection{Virtuous, Flowers}

El adjetivo 'virtuous' corre una suerte diversa en su traslado al español. Así, mientras Astrana Marín, Acuña, Fátima Auad y Mañé Garzón, Pérez Romero, Montezanti y Gómez Gil lo traducen por 'virtuoso/a' - término que incluye también, por supuesto, la idea de castidad—, Vedia, Damians de Bulart, Mujica Láinez, Méndez Herrera y Sordo prescinden totalmente de él y García Calvo, Pujol y Falaquera lo vierten por 'castos', con lo cual lo que es una sutil sugerencia en el original se transforma en el significado único en el texto de llegada. Finalmente, Dieste y Álvarez trasladan el término por 'nobles' y 'gentil', respectivamente, con lo que también en sus textos se pierden las diversas sugerencias presentes en el original.

Por lo que respecta a los diversos sentidos que confluyen en la forma 'flowers', los traductores españoles, al haber optado por el término 'flores' o 'rosas', se aproximan bastante al original ya que estos son semánticamente equivalentes al término de partida. Así

\footnotetext{
${ }^{32}$ Dieste, Damians de Bulart, Mujica Láinez, García Calvo, Fátima Auad y Mañé Garzón, Méndez Herrera, Pérez Romero, Montezanti, Falaquera y Gómez Gil.

${ }^{33}$ Astrana Marín, Vedia, Sordo, Pujol y Álvarez.
} 
pues, aunque el grado de proximidad depende del contexto en que cada uno de ellos los utiliza, por lo general, la respuesta de los traductores exhibe también una dosis de polisemia bastante aceptable.

\subsection{Lines of Life}

La exuberancia de connotaciones del sintagma 'lines of life' — que incluía sentidos tan diversos como la línea genealógica, el perfil físico del joven, la huella de la edad, los surcos de la mano, los versos e incluso quizá una alusión fálica - se refleja bastante bien en los textos de aquellos autores que optan por una traducción literal. Eso es lo que ocurre en las versiones de Dieste y Pérez Romero ('líneas de la vida'), Fátima Auad y Mañé Garzón ('las líneas de vida') y Montezanti ('Líneas de vida') ya que la palabra española líneas posee connotaciones muy parecidas. Sin embargo, en las respuestas de Acuña, García Calvo y Álvarez al traducir 'lines' por 'línea', es decir, en singular, se pierden algunas de esas connotaciones. Menos afortunadas resultan las traducciones de Astrana Marín, Mújica Láinez, Sordo, Falaquera y Gómez Gil ya que en todas ellas se vierte 'lines' por 'trazos', perdiéndose así algunas de las sugerencias más importantes. Por último, en las traducciones de Vedia, Méndez Herrera y Pujol, al trasladar 'lines' por 'vida', 'rasgos' y 'formas', respectivamente, se pierde la casi totalidad de los matices señalados; y en la de Damians de Bulart, sencillamente no se traduce el término.

\subsection{Repair, Keeps, To Give away Yourself y Drawn}

En cuanto al curioso y difícil juego homofónico de 'repair', ninguno de los traductores, como cabía esperar, logra reproducirlo en sus textos. En efecto, si de algún segmento concreto se puede afirmar que roza los límites de lo intraducible estamos sin duda ninguna ante ese caso.

Por el contrario, el juego de palabras presente en 'to give away yourself', así como la sugerente oposición entre el mencionado sintagma y la forma verbal 'keeps', no ha supuesto dificultad alguna para los traductores ${ }^{34}$. En concreto, en las fórmulas 'Dándoos vos mismo, os conservaréis...' (Astrana Marín), 'Y tendrás tú tu igual si quieres darte' (Vedia), 'Si quieres perdurar, has de entregarte' (Damians de Bulart), 'Si a ti mismo te entregas, quedarás' (Mújica Láinez), 'Dándote a otros para conservarte' (Acuña), 'Al entregarte tú, tú mismo has de guardarte' (García Calvo), 'el concederos a vos mismo os conserva' (Fátima Auad y Mañé Garzón), 'Te habrá de eternizar el entregarte' (Méndez Herrera), 'Entregándote, seguirás siendo tú' (Sordo), 'Entregarte a ti mismo perpetúa tu esencia' (Pérez Romero), 'Al darte te conservas' (Montezanti), 'Sólo dándote puedes seguir siendo tú mismo' (Pujol), 'La entrega de ti mismo te conserva a ti mismo' (Falaquera), 'Es tu entrega la que ha de perpetuarte' (Álvarez) y 'Dándote a ti mismo te conservarás' (Gómez Gil) se hallan no sólo la alusión del original al matrimonio y a la perpetuación sino también el contraste mencionado.

Finalmente, casi todos los traductores hallan una fórmula para traducir el participio pasado 'drawn' en la que se conjugan el arte del dibujo y la perpetuación de la especie (si bien en todas las traducciones se pierde la referencia fálica antes mencionada). En efecto, así se aprecia en las soluciones del tipo de 'en retrato trazado' (Astrana Marín), 'Viviente

\footnotetext{
${ }^{34}$ Tal vez la excepción la constituya el texto de Dieste: 'Aun mujer callada, conseguirás divulgarte / si te das a
} entender con tus propias dulces razones'. 
siempre por tu propio arte' (Vedia), 'dibujarte' (Acuña), 'pintado' (García Calvo y Méndez Herrera), 'representado' (Fátima Auad y Mañé Garzón), 'retrato' (Sordo, Montezanti, Álvarez y Gómez Gil), 'imagen' (Pujol) y 'retratado' (Mujica Láinez y Falaquera). En cuanto a las versiones de Dieste, Damians de Bulart y Pérez Romero se omite ese segmento que da lugar a tan interesante dilogía, con lo que, lógicamente, se pierden también los efectos estilísticos correspondientes.

\section{CONCLUSIÓN}

Como se ha dicho al principio de este trabajo, el juego verbal aparece como un elemento esencial de este soneto, tan necesario que si el traductor lo omite en el texto de llegada se mutila de forma drástica el contenido del poema original y, por tanto, la traducción resultante se alejará sobremanera de ese requisito fundamental de toda traducción: la fidelidad al original. En este caso concreto, y como ya se ha podido ver en el cotejo entre el texto original y las diversas traducciones, no existe ni un solo caso en el que se mantenga en su totalidad ese aspecto peculiar del soneto Shakespeariano. Esto no significa que las traducciones de los sonetos de Shakespeare al español carezcan por completo de valor pues, como se ha podido ver, en todas y cada una de las traducciones estudiadas se hallan soluciones, algunas muy ingeniosas, a los problemas que plantea el poema inglés. Y aquí reside el valor de los textos españoles por cuanto que cualquier solución que solvente fielmente cualquiera de los escollos presentes en el texto original posee un gran valor. Y ese valor deberá aprovecharlo el nuevo traductor de este poema al español incorporando en su texto los aciertos y soluciones de los traductores que le han precedido pues a través de este esfuerzo colectivo se logrará, con toda seguridad, una mayor aproximación al verdadero sentido del soneto shakespeariano.

\section{REFERENCIAS BIBLIOGRÁFICAS}

ÁLVAREZ, José María, William Shakespeare, Sonetos, Valencia, Pre-Textos, 1999.

ASTRANA MARÍN, Luis, William Shakespeare, Sonetos, Madrid, Editora Nacional, 1984, $1^{\text {a }}$ ed. 1929.

AUAD, Fátima/MAÑÉ GARZÓN, Pablo, William Shakespeare, Poesía Completa, Barcelona, Ediciones 29, 1975.

BARBER, C.L. "An Essay on Shakespeare's Sonnets" en Harold Bloom, ed. Shakespeare's Sonnets, Nueva York, Chelsea House, 1987, pp. 12-3.

BASILEO ACUÑA, José, Los Sonetos de William Shakespeare, Editorial Costa Rica, 1968.

BEECHING, H. C. ed., Sonnets of Shakespeare, Boston, Athenaeum Press, 1904.

BEVINGTON, D., ed., The Complete Works of Shakespeare, New York, Longman, 1997.

BOOTH, S., ed., Shakespeare's Sonnets, New Haven, Yale University Press, 1977.

BURROW, C., ed., The Complete Sonnets and Poems, Oxford: Oxford University Press, 2002.

BURTO, W., ed., The Sonnets, Londres, A Signet Classic, 1964. 
COLMAn, E. A. M., The Dramatic Use of Bawdy in Shakespeare, Londres, Longman, 1974.

DAMIANS DE BULART, Angelina, Guillermo Shakespeare, Sonetos, Barcelona, Montaner y Simón, S.A., 1944.

DIESTE, Eduardo, 21 sonetos de William Shakespeare, Montevideo, Editorial Independencia, 1943.

DODSWORTH, M., William Shakespeare, Londres, Everyman's Poetry, 1995.

DUNCAN-JONES, Katherine ed. Shakespeare's Sonnets, The Arden Shakespeare, 1997.

DURRANT, G., William Wordsworth, Cambridge at the University Press, 1969.

ELLIS, H. A., Shakespeare's Lusty Punning in 'Love's Labour's Lost' with Contemporary Analogues, Paris, Mouton, The Hague, 1973.

EMPSON, William, Seven Types of Ambiguity, Londres, Chatto y Windus, 1950.

EVANS, G.B., ed., The Sonnets, Cambridge University Press, 1996.

FABRICIUS, J., Syphilis in Shakespeare's England, Londres y Bristol, Pennsylvania, Jessica Kingsley Publishers, 1994.

FALAQUERA, Gustavo, William Shakespeare, Sonetos, Madrid, Hiperión, 1993.

FOSTER, J., A Shakespeare Word-Book, Nueva York, Russell and Russell, 1969.

GARCÍA CALVO, Agustín, The Sonnets/Sonetos de Amor, Barcelona, Anagrama, 1974.

GÓMEZ GIL, Alfredo, Los Sonetos de Shakespeare, Madrid, Edaf, 2000.

GRIVELET, M., "Shakespeare's 'War with Time': The Sonnets and Richard II", Shakespeare Survey, 23, pp. 69-78.

GRUNDY, J., "Shakespeare's Sonnets and the Elizabethan Sonneteers" en Peter Jones, ed. Shakespeare. The Sonnets, Londres, Macmillan, 1983, p. 44.

HENKE, J. T., Courtesans and Cuckolds. A Glossary of Renaissance Dramatic Bawdy (Exclusive of Shakespeare), Nueva York, Garland Publishers, 1979.

INGRAM, W. G. y T. REDPATH, eds. Shakespeare's Sonnets, University of London Press, 1964.

KERRIGAN, John, ed., The Sonnets and A Lover's Complaint, Nueva York, Penguin Books, 1986.

KÖKERITZ, H., Shakespeare's Pronunciation, New Haven, Yale Univ. Press, 1960.

LEVER, J. W., The Elizabethan Love Sonnet, Londres, Methuen, 1956.

MÉNDEZ HERRERA, José, William Shakespeare, Sonetos, Barcelona, Plaza \& Janés, S.A., 1976.

MONTEZANTI, Miguel Ángel, William Shakespeare, Sonetos completos, Universidad Nacional de la Plata, 1987.

MÚJICA LÁINEZ, Manuel, William Shakespeare, Sonetos, Madrid, Visor, 1983, 1ª ed. 1963.

ONIONS, C. T., A Shakespeare's Glossary, Oxford, Clarendon Press, 1986.

PADEL, John H., ed., New Poems by Shakespeare. Order and Meaning Restored to the Sonnets, Londres, The Herbert Press, 1981.

PARTRIDGE, Eric, Shakespeare's Bawdy, Londres, Routledge and Kegan Paul, 1968. 
PEQUiGNEY, J., "Such Is My Love": A Study of Shakespeare's Sonnets, Chicago y Londres, The University of Chicago Press, 1985.

PÉREZ ROMERO, Carmen, Monumentos de Amor: Sonetos de Shakespeare, Cáceres, Universidad de Extremadura, 1987.

POOLER, C.K., ed., The Works of Shakespeare: Sonnets, Londres, Methuen and Co. Ltd., 1931.

PUJOL, Carlos, William Shakespeare, Sonetos, Granada, Comares, 1990.

RAY, R., "Sonnet 16", The Explicator, XXXVIII, 1 (1979), pp. 24-5.

REED, E. B., ed., Shakespeare's Sonnets, New Haven, 1923.

RUBINSTEIN, F., A Dictionary of Shakespeare's Sexual Puns and their Significance, Londres, Macmillan; Salem, N. J., Salem House, 1984.

RUBINSTEIN, F. "Persistent Sexual Symbolism: Shakespeare and Freud", Literature and Psychology, XXXIV, 2 (1988), pp. 1-26.

SCHMIDT, A., Shakespeare's Lexicon and Quotation Dictionary, Nueva York, Dover Publications, Inc., 1971.

SEYMOUR-SMITH, M., ed., Shakespeare's Sonnets, Londres, Heinemann, 1963.

SORDO, Enrique, William Shakespeare. Sonetos, Barcelona, Los Libros de Plon, 1982.

TUCKER, T. G., ed., The Sonnets of Shakespeare, Cambridge at the University Press, 1924.

TUCKER BROOKE, C. F., Shakespeare's Sonnets, Oxford University Press, 1936.

VEDIA Y MITRE, Mariano de, Los Sonetos de Shakespeare, Buenos Aires, Editorial Guillermo Kraft Limitada, 1954.

VENDLER, H. The Art of Shakespeare's Sonnets, Cambridge, Massachusetts, The Belknap Press of Harvard University Press, 1997.

VILLON, François, Poésies completes, Le Livre de Poche, 1972.

WEBB, J. B., Shakespeare's Erotic Word Usage, Hastings, The Cornwallis Press, 1989.

WILLIAMS, Gordon, A Dictionary of Sexual Language and Imagery in Shakespearean and Stuart Literature, Londres, The Athlone Press, 1994.

WILSON, J. D., An Introduction to the Sonnets of Shakespeare, Cambridge University Press, 1963. 